\title{
Degradation of organic dye using a new homogeneous Fenton-like system based on hydrogen peroxide and a recyclable Dawson-type heteropolyanion
}

\author{
Abir Tabaï ${ }^{1}$ Ouahiba Bechiri ${ }^{1} \cdot$ Mostefa Abbessi $^{1}$
}

Received: 13 November 2015 / Accepted: 7 November 2016/Published online: 21 November 2016

(C) The Author(s) 2016. This article is published with open access at Springerlink.com

\begin{abstract}
The main objective of this work was to study the degradation of Acid Orange 7 (AO7) dye in aqueous solution by hydrogen peroxide using $\mathrm{HFe}_{2.5} \mathrm{P}_{2} \mathrm{~W}_{18} \mathrm{O}_{62}$ 23. $\mathrm{H}_{2} \mathrm{O}$ as a catalyst. $\mathrm{HFe}_{2.5} \mathrm{P}_{2} \mathrm{~W}_{18} \mathrm{O}_{62} 23 . \mathrm{H}_{2} \mathrm{O}$ is a recyclable DAWSON-type heteropolyanion. Effects of various experimental parameters of the oxidation reaction of the dye were investigated. The studied parameters were the initial $\mathrm{pH}$, the initial $\mathrm{H}_{2} \mathrm{O}_{2}$ concentration, the catalyst mass, and the dye concentration. The optimum conditions had been determined, and it was found that efficiency of degradation obtained was about $100 \%$. The optimal parameters were: initial $\mathrm{pH} 4 ;\left[\mathrm{H}_{2} \mathrm{O}_{2}\right]_{0}=2 \mathrm{mM}$; catalyst mass $0.01 \mathrm{~g}$; concentration of dye $30 \mathrm{mg} / \mathrm{L}$. Infrared spectroscopy analysis of the $\mathrm{HFe}_{2.5} \mathrm{P}_{2} \mathrm{~W}_{18} \mathrm{O}_{62} 23 . \mathrm{H}_{2} \mathrm{O}$ catalyst indicates that the catalyst showed good stability for degradation of AO7 even after second cycle.
\end{abstract}

Keywords Toxic dyes - Decolorization - Acid orange 7 . Water treatment · Oxidation · Homogeneous Fenton-like system

\section{Introduction}

The treatment of textile waste waters has always been a serious problem for these industries. These components sometimes are not biodegradable and are toxic enough for aquatic ecosystems [1]. Some classical methods such as adsorption on activated carbon, ozonation, reverse osmosis,

Ouahiba Bechiri

bechirio@yahoo.fr

1 Laboratory of Environmental Engineering, Department of Process Engineering, Faculty of Engineering, University of Annaba, P.O. Box 12, 23000 Annaba, Algeria ion exchange on synthetic adsorbent resins, flocculation, and decantation are available for removing dye from water. However, these methods have high operating cost [2] or are inefficient due to complex aromatic structure. Other alternatives to degrade recalcitrant organic pollutants are now being studied including advanced oxidation (AOPs) whose characteristic is to generate hydroxyl radicals $(\mathrm{OH})$, which are powerful oxidants [3].

These radicals are generated by Fenton's reagent $\left(\mathrm{Fe}^{2+} /\right.$ $\mathrm{H}_{2} \mathrm{O}_{2}$ ), which has been the subject of many studies in the degradation of organic matter [4]. However, the disadvantage of the method lies in Fenton rejection of a significant amount of sludge $\mathrm{Fe}^{2+}$ and $\mathrm{Fe}^{3+}$ [5], which requires separation or removal, thus increasing the operational cost. To solve this problem, many studies have focused on the use of a modified Fenton process (Fenton-Like) to treat waste waters. A method which relies on the use iron incorporated in the recyclable compounds [6]. In this work, a new homogeneous Fenton-like system based on hydrogen peroxide and a recyclable Dawson-type heteropolyanion (Fig. 1) [7].

$\left(\mathrm{HFe}_{2.5} \mathrm{P}_{2} \mathrm{~W}_{18} \mathrm{O}_{62} 23 . \mathrm{H}_{2} \mathrm{O} / \mathrm{H}_{2} \mathrm{O}_{2}\right)$ system was used for decolorization of Acid Orange 7 (AO7) (also known as Orange II).

Acid Orange 7 is one of the dyes that are produced in large amounts in the world. It is commonly used in pharmaceutical, food, and cosmetics industries. Acid Orange 7 is an azoique dye used in dyeing of silk and wool. For these qualities, Acid Orange 7 is much used in the textile industry. The molecular structure of azo-dye Orange II is shown in Fig. 2. Acid Orange 7 is not amenable to conventional biological treatment [8].

The aim of the study is to examine the influence of different parameters such as the solution $\mathrm{pH}$, the catalyst mass, the concentration of $\mathrm{H}_{2} \mathrm{O}_{2}$, and the initial dye concentration on the degradation of Acid Orange 7 by $\mathrm{H}_{2} \mathrm{O}_{2}$ 


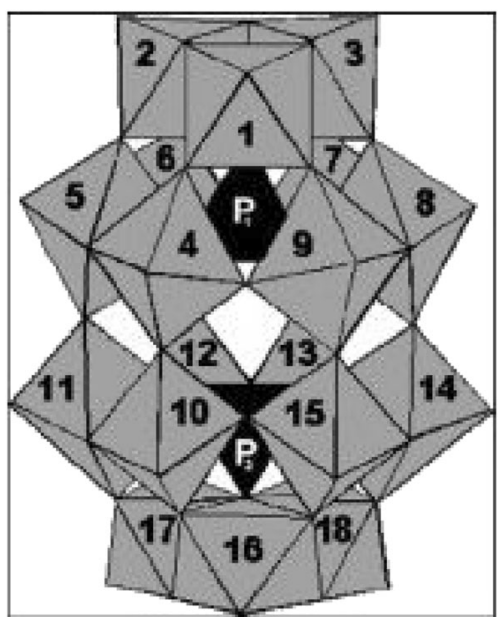

Fig. 1 Polyhedral representation of the Dawson structure of polyanion

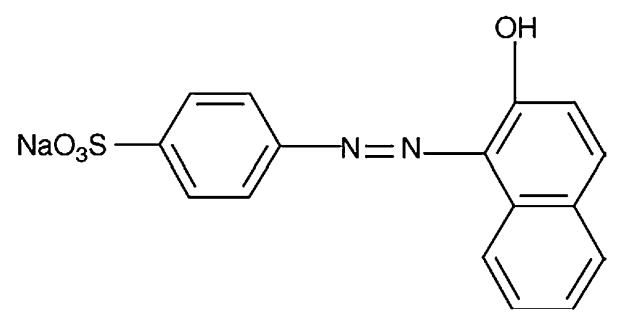

Fig. 2 Chemical structure of Acid Orange 7 (AO7)

using $\mathrm{HFe}_{2.5} \mathrm{P}_{2} \mathrm{~W}_{18} \mathrm{O}_{62} 23 . \mathrm{H}_{2} \mathrm{O}$ as a catalyst. The mechanism of the reaction and catalytic stability were studied.

\section{Experimental section}

\section{Synthesis of catalyst $\mathrm{HFe}_{2.5} \mathrm{P}_{2} \mathrm{~W}_{18} \mathrm{O}_{62} 23 . \mathrm{H}_{2} \mathrm{O}$ [9]}

$\mathrm{HFe}_{2.5} \mathrm{P}_{2} \mathrm{~W}_{18} \mathrm{O}_{62} 23 . \mathrm{H}_{2} \mathrm{O}$

$5 \mathrm{~g}(1.088 \mathrm{~mol})$ of $\mathrm{H}_{6} \mathrm{P}_{2} \mathrm{~W}_{18} \mathrm{O}_{62}$ was dissolved in $20 \mathrm{~mL}$ of water at room temperature and $0.767 \mathrm{~g}$ of solid $\mathrm{FeCl}_{2}, 6$ $\mathrm{H}_{2} \mathrm{O}$ (3.26 mol) was then added. The mixture was then stirred for $10 \mathrm{~min}$. Yellow powder was obtained after five days by slow evaporation.

$\mathrm{H}_{6} \mathrm{P}_{2} \mathrm{~W}_{18} \mathrm{O}_{62}$ was prepared, starting from the substance mother $\left(\mathrm{K}_{6} \mathrm{P}_{2} \mathrm{~W}_{18} \mathrm{O}_{62}, \mathrm{nH}_{2} \mathrm{O}\right)^{6-}$, by extraction with ether in hydrochloric acid medium according to the methods described in the literature [10].

\section{Behavior of AO7 oxidation using $\mathrm{HFe}_{2.5} \mathrm{P}_{2} \mathrm{~W}_{18} \mathrm{O}_{62}$ 23. $\mathrm{H}_{2} \mathrm{O} / \mathrm{H}_{2} \mathrm{O}_{2}$ system}

\section{Reagents}

The 4-(2-hydroxy-1-naphthylazo) benzene sulfonic acid sodium salt, commonly named orange II or Acid Orange 7
(AO7) (90\%) was obtained from Aldrich $\left(\mathrm{H}_{2} \mathrm{O}_{2} 35 \%\right.$, W/W) was purchased from Aldrich Chemical Company. All other reagents $\left(\mathrm{NaOH}\right.$ or $\left.\mathrm{H}_{2} \mathrm{SO}_{4}\right)$ that used in this study were analytical grade.

\section{Procedures and analysis}

The experiments were performed in a reactor batch of $500 \mathrm{~mL}$ capacity. Various solutions of AO7 were prepared at different concentrations. They were then homogenized by stirring them until the dye is completely dissoluted of the dye. $\mathrm{pH}$ was adjusted using $0.1 \mathrm{~N} \mathrm{H}_{2} \mathrm{SO}_{4}$ or $\mathrm{NaOH}$ aqueous solutions. In all experiments $100 \mathrm{~mL}$ of dyes (30 $\mathrm{mg} / \mathrm{L})$ solution containing the appropriate quantity of catalyst and $\mathrm{H}_{2} \mathrm{O}_{2}$ was magnetically stirred at room temperature. The AO7 decreasing concentration of dye was monitored by a $6705 \mathrm{UV}$ visible spectrophotometer JENWAY. The Wave length corresponding to the maximum absorbance is given below: $\lambda_{\max }=486 \mathrm{~nm}$ [11].

The resolution of the wave length and bandwidth was 1 and $0.5 \mathrm{~nm}$. The cell used during the experiments was made of $1 \mathrm{~cm}$ thick quartz.

\section{Effects of operational parameters on AO7 oxidation}

The oxidation of AO7 by $\mathrm{H}_{2} \mathrm{O}_{2}$ using $\left(\mathrm{HFe}_{2.5} \mathrm{P}_{2} \mathrm{~W}_{18} \mathrm{O}_{61}\right.$ $23 \mathrm{H}_{2} \mathrm{O}$ ) as a catalyst has been studied according to the following factors: initial $\mathrm{pH}$ of the solution, $\mathrm{H}_{2} \mathrm{O}_{2}$ concentration, mass of the catalyst $\left(\mathrm{HFe}_{2.5} \mathrm{P}_{2} \mathrm{~W}_{18} \mathrm{O}_{61} 23 \mathrm{H}_{2} \mathrm{O}\right)$, and dye concentration.

The oxidation efficiency (discoloration) was determined as it is shown below [12]:

$\mathrm{DE}=\left[\left(C_{i}-C_{f}\right) / C_{i}\right] \times 100$

DE: discoloration efficiency; $C_{i}$ : Initial dye concentration; $C_{f}$ : final dye concentration.

Effect of solution $\mathrm{pH}$ The $\mathrm{pH}$ value of dye solution has significant influence on the catalytic system efficiency because: (1) it can affect the catalyst stability and (2) it influences the catalytic reaction which controls the production rate of hydroxyl radicals [13]. To find the optimum $\mathrm{pH}$ for the decolorization of $\mathrm{AO} 7$, a series of experiments at initial $\mathrm{pH}$ value in the range 3-8 was conducted.

Figure 3 illustrates the effect of $\mathrm{pH}$ on the discoloration efficiency of AO7 in water. It was found that the discoloration efficiency of AO7 is strongly $\mathrm{pH}$ dependent. The optimal $\mathrm{pH}$ is about 4 giving discoloration efficiency equal to $94.25 \%$. This result can be explained by the stability of the catalyst at this $\mathrm{pH}$. Also, $\mathrm{H}_{2} \mathrm{O}_{2}$ molecules are unstable in alkaline solution and therefore, the degradation of dye decreases in alkaline solution [14].

The optimal value is chosen $\mathrm{pH} 4$. 


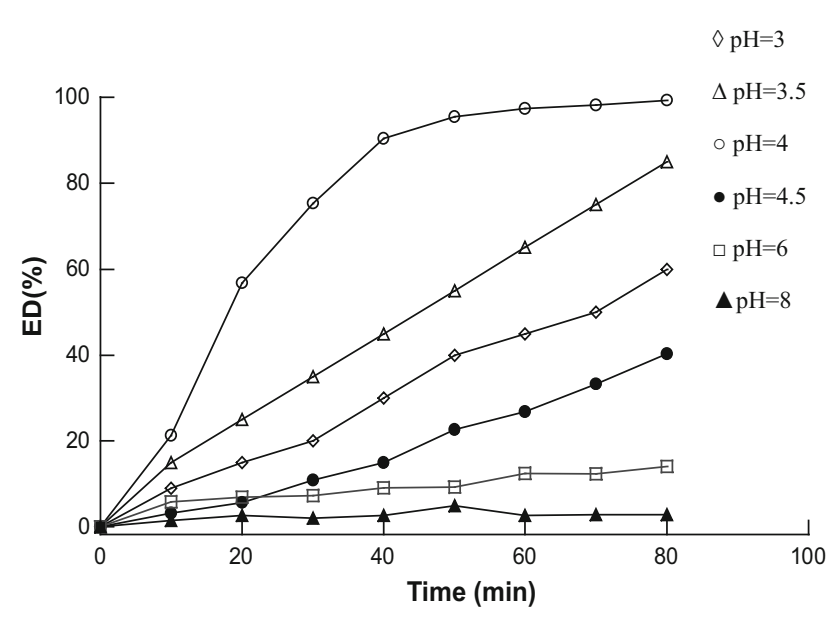

Fig. 3 Effect of solution $\mathrm{pH}$ on $\mathrm{AO} 7$ oxidation $\left([\mathrm{AO} 7]_{0}=30 \mathrm{mg} / \mathrm{L}\right.$, $\left[\mathrm{H}_{2} \mathrm{O}_{2}\right]_{0}=0.11 \mathrm{mM}, \quad \mathrm{m} \quad\left(\mathrm{HFe}_{2.5} \mathrm{P}_{2} \mathrm{~W}_{18} \mathrm{O}_{62} \quad 23 . \mathrm{H}_{2} \mathrm{O}\right)=0.01 \mathrm{~g}$, $T=25{ }^{\circ} \mathrm{C}$ )

Effect of the nature of the acid used to adjust the $p H \quad$ The oxidation of the dye by the Fenton-like process can be influenced by the presence of various ions such as $\mathrm{SO}_{4}{ }^{2-}$, $\mathrm{NO}^{3-}, \mathrm{Cl}^{-}$, and $\mathrm{PO}_{4}{ }^{3-}$ [15]. To evaluate the influence of these anions, we adjusted the $\mathrm{pH}$ of an aqueous solution of AO7 by different acids $\mathrm{H}_{2} \mathrm{SO}_{4}, \mathrm{HNO}_{3}, \mathrm{HCl}$, and $\mathrm{H}_{3} \mathrm{PO}_{4}$ in similar operating conditions to those previously established.

Figure 4 shows the effect of these acid ions (chloride, sulfate, nitrate, and phosphate) on the dye oxidation. It appears that the presence of phosphate ions inhibits the oxidation of the dye using $\mathrm{HFe}_{2.5} \mathrm{P}_{2} \mathrm{~W}_{18} \mathrm{O}_{62} 23 . \mathrm{H}_{2} \mathrm{O} / \mathrm{H}_{2} \mathrm{O}_{2}$ system.

Sulfate and nitrate ions have virtually no effect on the discoloration of AO7. However, depending on the nature of the acids, the discoloration efficiency is about $94.25,94.35$, 96.09 , and $03.06 \%$ in the presence of $\mathrm{H}_{2} \mathrm{SO}_{4}, \mathrm{HNO}_{3}, \mathrm{HCl}$,

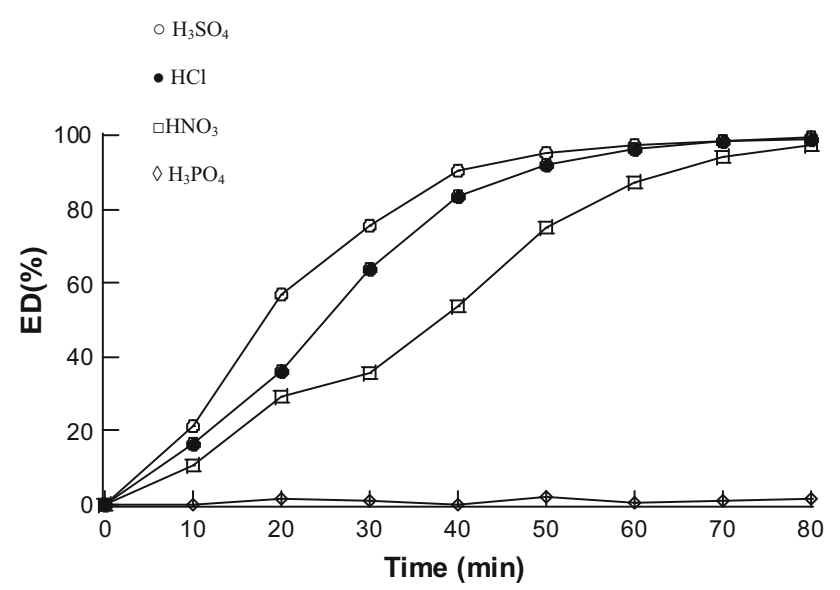

Fig. 4 Effect of the nature of the acid used to adjust the $\mathrm{pH}(\mathrm{pH} 4$, $[\mathrm{AO} 7]_{0}=30 \mathrm{mg} / \mathrm{L}, \quad\left[\mathrm{H}_{2} \mathrm{O}_{2}\right]_{0}=0.11 \mathrm{mM}, \quad \mathrm{m} \quad\left(\mathrm{HFe}_{25} \mathrm{P}_{2} \mathrm{~W}_{18} \mathrm{O}_{62}\right.$ 23. $\left.\mathrm{H}_{2} \mathrm{O}\right)=0.01 \mathrm{~g}, T=25^{\circ} \mathrm{C}$ ) and $\mathrm{H}_{3} \mathrm{PO}_{4}$ acids, respectively. These results agree with those found at the degradation of other organic pollutants [16]. We can deduce that $\mathrm{H}_{2} \mathrm{SO}_{4}, \mathrm{HNO}_{3}$, and $\mathrm{HCl}$ acids lead almost to the same efficiency, but in the presence of $\mathrm{H}_{3} \mathrm{PO}_{4}$ it is too low. The inhibitory effect of phosphate ions may be due to the trapping of $\mathrm{OH}$ radicals.

Effect of catalyst mass The effect of the catalyst mass was investigated, keeping operational parameters identical to those of the above-mentioned experiment. The following catalyst quantities have been used: $0.005 ; 0.008 ; 0.01$; $0.02 \mathrm{~g}$. The results are illustrated in Fig. 5 .

These results show that the discoloration efficiency of AO7 oxidation increases when increasing the catalytic mass up to $0.01 \mathrm{~g}$ where the decolorization efficiency is optimal. Beyond this value, there is a decrease of the discoloration efficiency. The excess of the catalyst does not appear to ply a positive role in the $\mathrm{AO} 7$ oxidation using $\mathrm{HFe}_{2.5} \mathrm{P}_{2} \mathrm{~W}_{18} \mathrm{O}_{62} 23 . \mathrm{H}_{2} \mathrm{O} / \mathrm{H}_{2} \mathrm{O}_{2}$ system. This result is in good agreement with literature $[12,13,17]$ : the decrease of the discoloration efficiency of AO7 when increasing the mass of the catalyst can be explained by the presence of side reaction consuming the radicals hydroxyls. The mass of catalyst that gives the best result is $0.01 \mathrm{~g}$.

Effect of $\mathrm{H}_{2} \mathrm{O}_{2}$ concentration The effect of $\mathrm{H}_{2} \mathrm{O}_{2}$ concentration on $\mathrm{AO} 7$ decolorization was studied in the range 0.04-0.44 mmol. The results are illustrated in Fig. 6.

The results indicate that the degradation of $\mathrm{AO} 7$ was increased by increasing the concentration of $\mathrm{H}_{2} \mathrm{O}_{2}$ up to a value of concentration of $\mathrm{H}_{2} \mathrm{O}_{2}$ equal to $2 \mathrm{mM}$.

Decolorization of certain dyes, mainly azo, with activated hydrogen peroxide in homogeneous systems, using different soluble catalysts (heteropolyanions) was already studied [18].

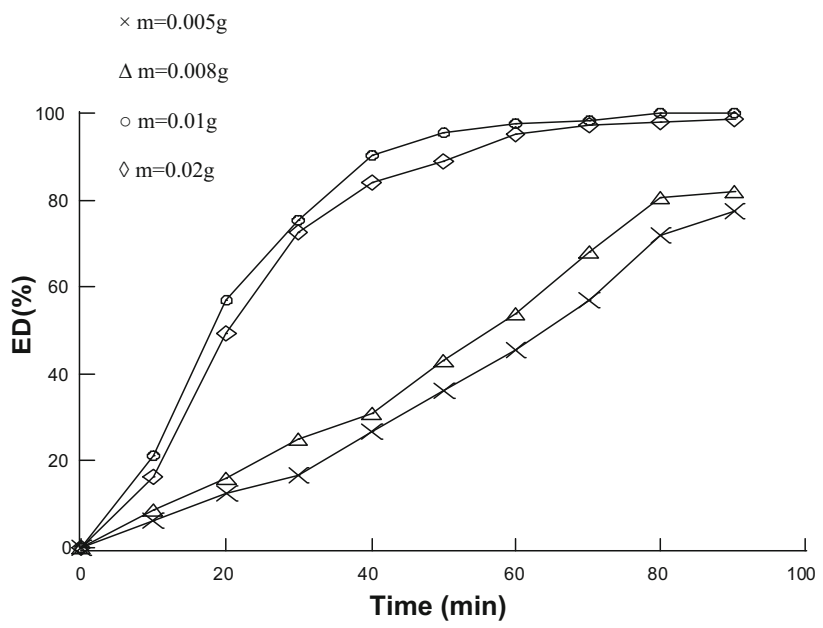

Fig. 5 Effect of catalyst mass on $\mathrm{AO} 7$ oxidation (pH 4, $[\mathrm{AO} 7]_{0}=30 \mathrm{mg} / \mathrm{L},\left[\mathrm{H}_{2} \mathrm{O}_{2}\right]_{0}=0.11 \mathrm{mM}, T=25^{\circ} \mathrm{C}$ ) 
The activation of hydrogen peroxide by homogeneous catalysts was attributed to the formation of highly active hydroxyl radicals [19]. High concentrated $\mathrm{H}_{2} \mathrm{O}_{2}$ solution undergoes self quenching of $\mathrm{OH}$ radicals, with formation of hydroperoxyl radicals $\mathrm{HO}_{2}$. Although $\mathrm{HO}_{2}$ is an effective oxidant itself, its oxidation potential is much lower than that of $\mathrm{OH}$ radicals [20].

$$
\begin{aligned}
& \mathrm{H}_{2} \mathrm{O}_{2}+\mathrm{OH} \rightarrow \mathrm{H}_{2} \mathrm{O}+\mathrm{HO}_{2}, \\
& \mathrm{HO}_{2}+\mathrm{OH} \rightarrow \mathrm{H}_{2} \mathrm{O}+\mathrm{O}_{2}, \\
& \mathrm{OH}+\mathrm{OH} \rightarrow \mathrm{H}_{2} \mathrm{O}_{2} .
\end{aligned}
$$

It can be postulated that $\mathrm{H}_{2} \mathrm{O}_{2}$ should be added at an optimum concentration to achieve the best degradation. Hence, $0.2 \mathrm{mM} / \mathrm{L}$ of $\mathrm{H}_{2} \mathrm{O}_{2}$ appears as an optimal.

Radical scavenging experiments and possible reaction mechanism In general, $\mathrm{OH}$ radicals are known as a key active species in the catalytic oxidation process. $\mathrm{OH}$ radicals are powerful oxidants for many organic molecules.

Ethanol, methanol, and 2-propanol are known as $\mathrm{OH}$ scavengers [21-24]. These reagents were introduced into the reaction system to capture $\mathrm{OH}$ in the oxidation of $\mathrm{AO} 7$ process. The results are illustrated in Fig. 7.

These results show that the addition of $\mathrm{OH}$ scavenger reagents causes a sharp decrease in the degradation of $\mathrm{AO} 7$, and the discoloration efficiency of $\mathrm{AO} 7$ from $100 \%$ to $1.6,2.08$, and $2.53 \%$ in the presence of methanol, ethanol, and 2-propanol, respectively. According to the above discussion, it is furthermore confirmed that the degradation of AO7 molecules is dependent on the availability of $\mathrm{OH}$ radical species. $\mathrm{OH}$ radicals make a major contribution to degradation of $\mathrm{AO} 7 . \mathrm{OH}$ scavenger reagents added consume $\mathrm{OH}$ radical species and less will

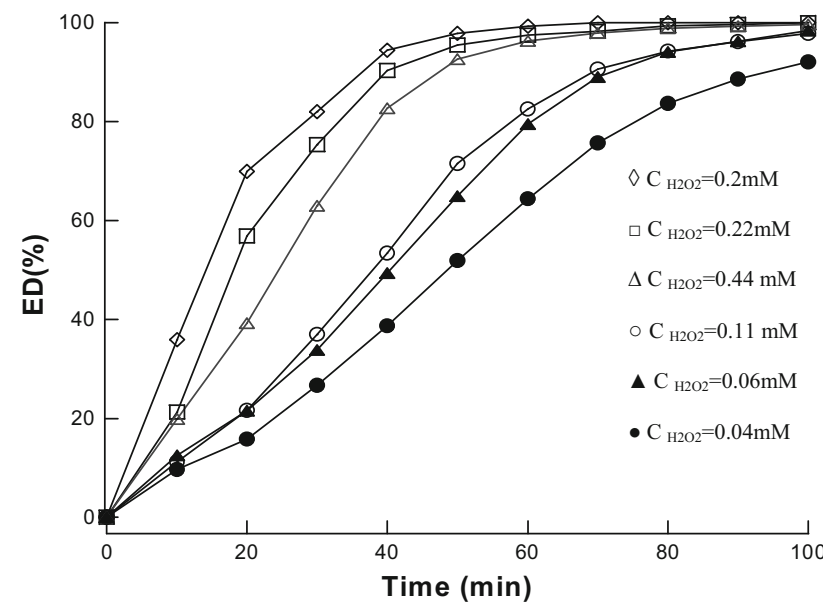

Fig. 6 Effect of initial $\mathrm{H}_{2} \mathrm{O}_{2}$ concentration on $\mathrm{AO} 7$ oxidation ( $\mathrm{pH} 4$, $[\mathrm{AO} 7]_{0}=30 \mathrm{mg} / \mathrm{L}, \quad \mathrm{m} \quad\left(\mathrm{HFe}_{2.5} \mathrm{P}_{2} \mathrm{~W}_{18} \mathrm{O}_{62} \quad 23 . \mathrm{H}_{2} \mathrm{O}\right)=0.01 \mathrm{~g}$, $\left.T=25{ }^{\circ} \mathrm{C}\right)$

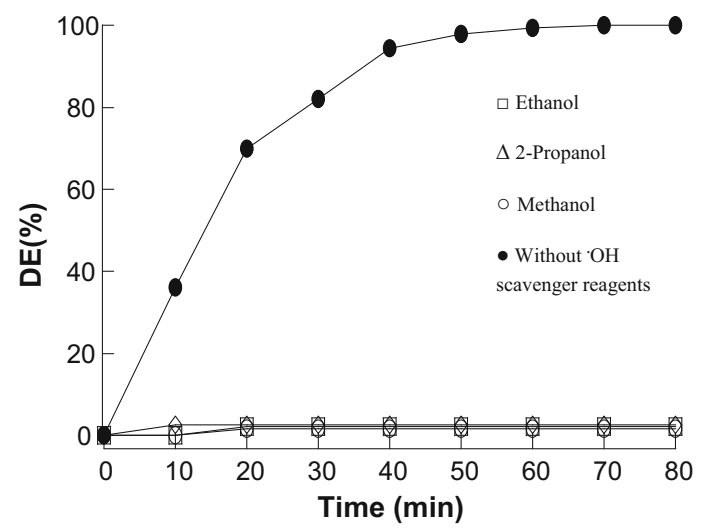

Fig. 7 Effect of addition of $\mathrm{OH}$ scavenger reagents on $\mathrm{AO} 7$ oxidation $\quad\left(\mathrm{pH} \quad 4, \quad[\mathrm{AO} 7]_{0}=30 \mathrm{mg} / \mathrm{L}, \quad \mathrm{m} \quad\left(\mathrm{HFe}_{2.5} \mathrm{P}_{2} \mathrm{~W}_{18} \mathrm{O}_{62}\right.\right.$ 23. $\left.\left.\mathrm{H}_{2} \mathrm{O}\right)=0.01 \mathrm{~g}, T=25^{\circ} \mathrm{C}\right)$

be available for the degradation of the dye molecules, hence the lower discoloration efficiency.

Also, it was shown [25] that the action of $\mathrm{H}_{2} \mathrm{O}_{2}$ on a complex containing $\mathrm{Fe}^{3+}$ resulted in the reduction of $\mathrm{Fe}^{3+}$ to $\mathrm{Fe}^{2+}$ with apparition of $\mathrm{HO}_{2}$.

The action of $\mathrm{H}_{2} \mathrm{O}_{2}$ on the complex of $\mathrm{Fe}^{2+}$ leads to the generation of hydroxyl radicals $\mathrm{OH}$. These hydroxyl radicals cause the degradation of the dye.

In agreement with the results found and the mechanism proposed below, we can propose the following mechanism:

$\mathrm{P}_{2} \mathrm{~W}_{18} \mathrm{Fe}^{3+}+\mathrm{H}_{2} \mathrm{O}_{2} \rightarrow \mathrm{P}_{2} \mathrm{~W}_{18} \mathrm{Fe}^{2+}+\mathrm{HO}_{2}+\mathrm{H}^{+}$,

$\mathrm{P}_{2} \mathrm{~W}_{18} \mathrm{Fe}^{2+}+\mathrm{H}_{2} \mathrm{O}_{2} \rightarrow \mathrm{P}_{2} \mathrm{~W}_{18} \mathrm{Fe}^{3+}+2 \cdot \mathrm{OH}$.

The degradation of $\mathrm{AO} 7$ by $\mathrm{H}_{2} \mathrm{O}_{2}$ catalyzed with $\mathrm{HFe}_{2.5} \mathrm{P}_{2} \mathrm{~W}_{18} \mathrm{O}_{62}$ 23. $\mathrm{H}_{2} \mathrm{O}$ heteropolyanion can be well supported by the change in the UV-Vis absorption spectrum over the course of degradation (Fig. 8). The AO7 spectrum was characterized by the chromophore that contained azo linkage [26] in the visible range at 484 and $430 \mathrm{~nm}$ corresponding to the hydrazone and azo form. In the ultraviolet region, the absorbance peaks at 230 and $310 \mathrm{~nm}$ are due to the benzene and naphthalene rings, respectively. These four characteristic bands were markedly weakened during the degradation reaction, tending to disappear completely after $60 \mathrm{~min}$, without the appearance of new absorption bands in the visible or ultraviolet regions due to destruction of the chromophoric and auxochromic structures by the homogeneous Fenton-like reaction.

Effect of the AO7 concentration It is important from an application point of view to study the dependence of removal efficiency on the initial concentration of the colorant $(\mathrm{AO} 7)$.

To determine the effect of $\mathrm{AO} 7$ concentration on discoloration efficiency, a series of experiments was realized 
Fig. 8 UV-Vis spectra of AO7 water solutions during the treatment process with $\mathrm{Fe}(\mathrm{III}) \mathrm{P}_{2} \mathrm{~W}_{18} / \mathrm{H}_{2} \mathrm{O}_{2}$ system ( $\mathrm{pH}$ 4, $\left[\mathrm{H}_{2} \mathrm{O}_{2}\right]_{0}=0.2 \mathrm{mM}, \mathrm{m}$ $\left(\mathrm{HFe}_{2.5} \mathrm{P}_{2} \mathrm{~W}_{18} \mathrm{O}_{62}\right.$ 23. $\left.\mathrm{H}_{2} \mathrm{O}\right)=0.01 \mathrm{~g}$, $\left.[\mathrm{AO} 7]=30 \mathrm{mg} / \mathrm{L}, T=25^{\circ} \mathrm{C}\right)$

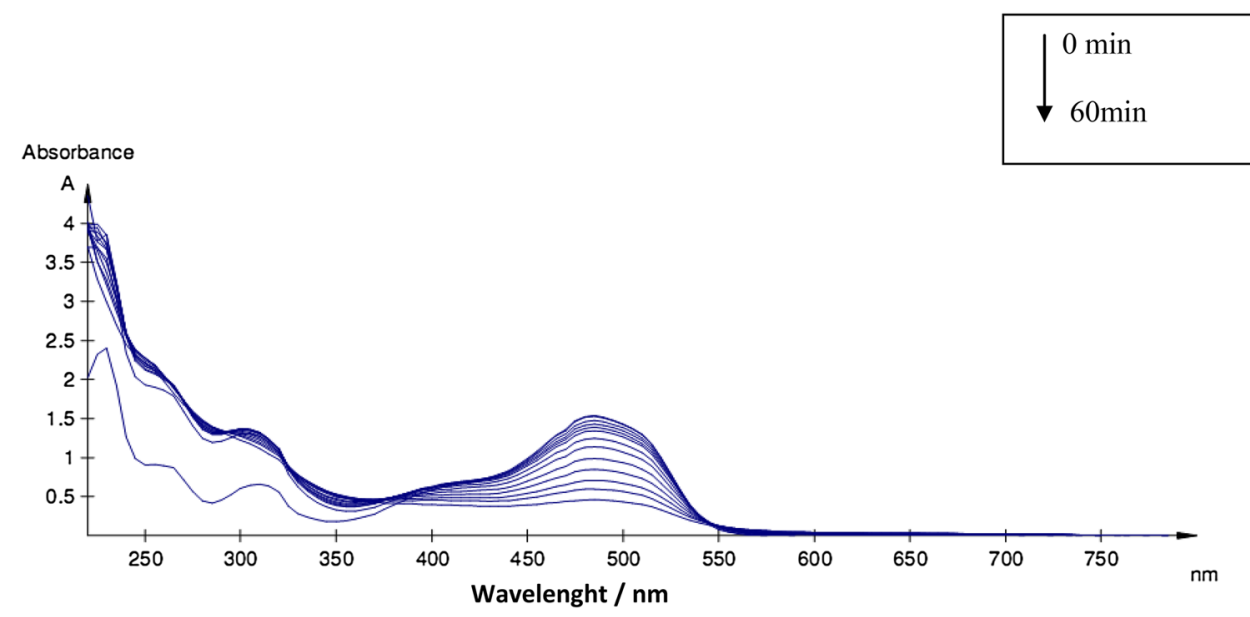

between 5 and $50 \mathrm{mg} / \mathrm{L}$. The variation of the discoloration efficiency of the AO7 dye with $\mathrm{H}_{2} \mathrm{O}_{2}$ and $\mathrm{HFe}_{2.5} \mathrm{P}_{2} \mathrm{~W}_{18} \mathrm{O}_{61}$ $23 \mathrm{H}_{2} \mathrm{O}$ catalyst as a function of initial dye concentration is represented in Fig. 9. The results show that the discoloration efficiency increases with increasing of dye concentration up to a value equal to $30 \mathrm{mg} / \mathrm{L}$, but above it the discoloration efficiency decreases.

This result can be explained as follows:

At low concentration of dye, the discoloration efficiency is lower (ED 39\% for the concentration of AO7 $5 \mathrm{mg} / \mathrm{L}$ ). These results concur with those found in literature [27-29]. This phenomenon can be explained by the effect of $\mathrm{H}_{2} \mathrm{O}_{2}$ concentration is in excess compared to latter and can cause the scavenging effect (the reaction of $\mathrm{H}_{2} \mathrm{O}_{2}$ and $\mathrm{OH}$ in aqueous solution).

- At higher concentration of dye, the discoloration efficiency decreases (ED $48 \%$ for the concentration of AO7 $50 \mathrm{mg} / \mathrm{L}$ ). This phenomenon can be explained by the fact that increasing the initial concentration of dye leads to an increase in the number of molecules of (AO7), while the number of the radical's hydroxyls remains constant $\left(\mathrm{H}_{2} \mathrm{O}_{2}\right.$ concentration and catalyst kept

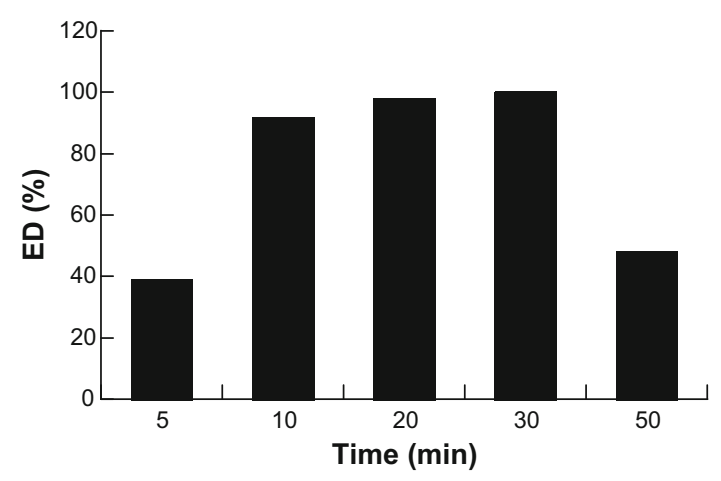

Fig. 9 Effect of initial dye concentration on $\mathrm{AO} 7$ oxidation. ( $\mathrm{pH} 4$, $\left[\mathrm{H}_{2} \mathrm{O}_{2}\right]_{0}=0.2 \mathrm{mM}, \quad \mathrm{m} \quad\left(\mathrm{HFe}_{2.5} \mathrm{P}_{2} \mathrm{~W}_{18} \mathrm{O}_{62} \quad 23 . \mathrm{H}_{2} \mathrm{O}\right)=0.01 \mathrm{~g}$, $\left.T=25{ }^{\circ} \mathrm{C}\right)$ constant), thereby causing a decrease in the discoloration efficiency [19, 27].

\section{Stability and recycling of the catalyst}

After reaction, we have tried to recover the catalyst $\mathrm{P}_{2} \mathrm{~W}_{18} \mathrm{Fe}^{3+}$. The method used is its precipitation, as potassium salt, by adding a mass of $\mathrm{KCl}$ in the solution after complete discoloration in a basic medium. The resulting precipitate was characterized by infrared spectroscopy. The spectra are illustrated in Fig. 10.

The spectrum of the recovered heteropolyanion is identical to that of the initially added heteropolyanion. We can therefore conclude that the catalyst remains stable and robust after the reaction.

Figure 11 shows the catalytic performance of recovered catalyst after four cycles through the oxidation of AO7 dye, by hydrogen peroxide.

After second cycle, the catalyst did not exhibit significant loss of catalytic activity and the discoloration efficiency was 100 . AO7 degradation decreases only from 100

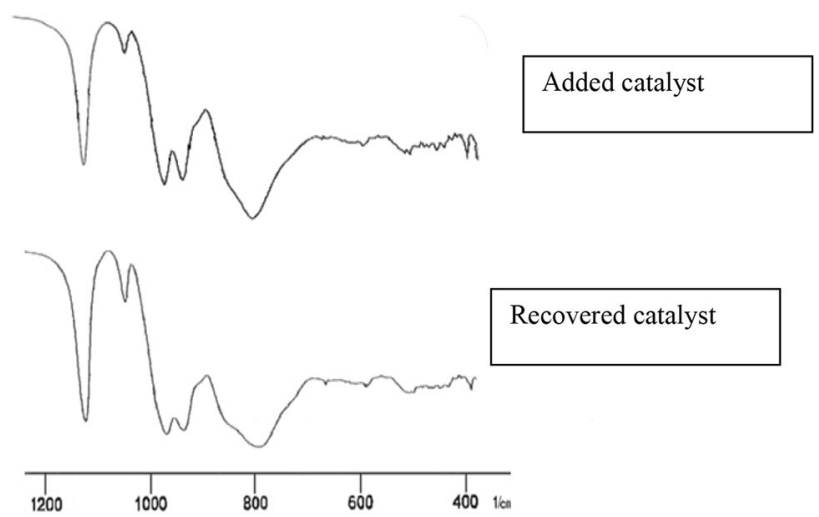

Fig. 10 IR spectra of $\mathrm{HFe}_{2.5} \mathrm{P}_{2} \mathrm{~W}_{18} \mathrm{O}_{62} \quad 23 . \mathrm{H}_{2} \mathrm{O}$ and recovered $\mathrm{HFe}_{2.5} \mathrm{P}_{2} \mathrm{~W}_{18} \mathrm{O}_{62} 23 . \mathrm{H}_{2} \mathrm{O}$ 


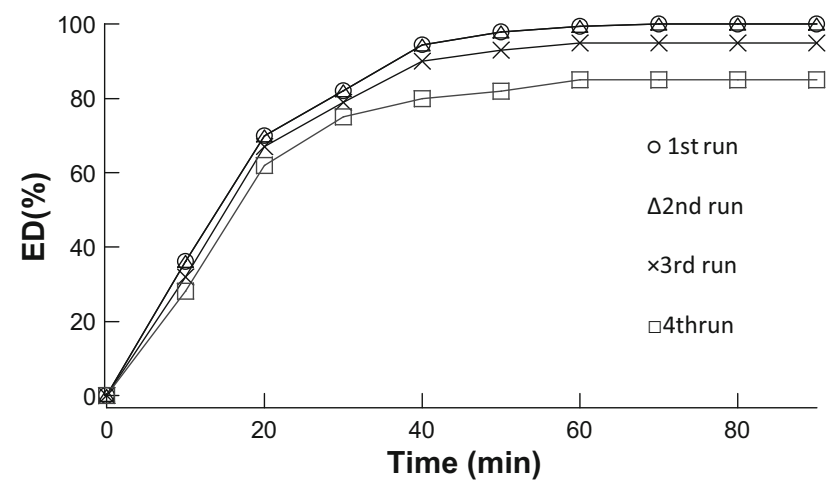

Fig. 11 Catalytic performance of recovered catalyst after four cycles through the oxidation of $\mathrm{AO} 7$ dye by hydrogen peroxide. $(\mathrm{pH} 4$, $\left[\mathrm{H}_{2} \mathrm{O}_{2}\right]_{0}=0.2 \mathrm{mM}, \quad \mathrm{m} \quad\left(\mathrm{HFe}_{2.5} \mathrm{P}_{2} \mathrm{~W}_{18} \mathrm{O}_{62} \quad 23 . \mathrm{H}_{2} \mathrm{O}\right)=0.01 \mathrm{~g}$, $T=25{ }^{\circ} \mathrm{C}$, [AO7] $=30 \mathrm{mg} / \mathrm{L}$ )

to $95 \%$ in three cycles. In four cycles, AO7 degradation decreases from 100 to $89 \%$.

This result is in good agreement with the literature [28]. The loss of activity can be explained by to poisoning of the active catalytic sites due to adsorbed organic species. However, this could be avoided by placing the catalyst in an oven at $180{ }^{\circ} \mathrm{C}$, to enhance the organic solvent.

\section{Conclusion}

$\mathrm{Fe}(\mathrm{III})$-phosphotunstate $/ \mathrm{H}_{2} \mathrm{O}_{2}$ system is a new homogeneous Fenton-like system that is capable of oxidizing organic dye compounds. The experimental results show that the initial $\mathrm{pH}$, the initial concentration of $\mathrm{H}_{2} \mathrm{O}_{2}$, $\mathrm{Fe}(\mathrm{III}) \mathrm{P}_{2} \mathrm{~W}_{18}, \mathrm{AO} 7$ concentration, had a great influence on the degradation of AO7 dye. It is approximately $100 \%$ dye which has been eliminated the $\mathrm{Fe}(\mathrm{III}) \mathrm{P}_{2} \mathrm{~W}_{18} / \mathrm{H}_{2} \mathrm{O}_{2}$ on the following operating conditions: $\mathrm{pH} 4$, catalyst mass $0.01 \mathrm{~g}$, $\left[\mathrm{H}_{2} \mathrm{O}_{2}\right]_{0}=2 \mathrm{~m} \mathrm{M}$. The molar ratio $\mathrm{H}_{2} \mathrm{O}_{2} / \mathrm{AO}_{7}=0.02$. The possibility of recovery of the catalyst after reaction is verified by adding a mass of $\mathrm{KCl}$ in the solution after complete discoloration. The stability of reused catalyst is confirmed after second cycle.

This system constitutes simple and effective method compared to those previously reported for the oxidation of Acid Orange $7[29,30]$.

Acknowledgements This work was supported by the Engineering Environmental Laboratory of Badji Mokhtar University (AnnabaAlgeria). This work is a tribute to the late Professor Mostefa Abbessi, God rest his soul.

Open Access This article is distributed under the terms of the Creative Commons Attribution 4.0 International License (http://crea tivecommons.org/licenses/by/4.0/), which permits unrestricted use, distribution, and reproduction in any medium, provided you give appropriate credit to the original author(s) and the source, provide a link to the Creative Commons license, and indicate if changes were made.

\section{References}

1. Fernández J, Kiwi J, Baeza J, Freer J, Lizama C, Mansilla HD (2004) Orange II photocatalysis on immobilised $\mathrm{TiO}_{2}$, Effect of the $\mathrm{pH}$ and $\mathrm{H}_{2} \mathrm{O}_{2}$. Appl Catal B Environ 48:205-211

2. Rajeshwar K, Osugi ME, Chanmanee W, Chenthamarakshan CR, Zanoni MVB, Kajitvichyanukul P, Krishnan-Ayer R (2008) Heterogeneous photocatalytic treatment of organic dyes in air and aqueous media. Photochemrev 9:171-192

3. Zhang Y, He C, Deng J, Tu Y, Liu J, Xiong Y (2009) PhotoFenton-like catalytic activity of nano-lamellar $\mathrm{Fe}_{2} \mathrm{~V}_{4} \mathrm{O}_{13}$ in the degradation of organic pollutants. Res Chem Intermed 35:727-737

4. Medien HAA, Khalil SME (2010) Kinetics of the oxidative decolorization of some organic dyes utilizing Fenton-like reaction in water. J King Saud Univ 22:147-153

5. Duesterberg CK, Mylon SE, Waite TD (2008) pH effects on ironcatalyzed oxidation using Fenton's reagent. Environ Sci Technol 42:8522-8527

6. Hsueh CL, Huang YH, Wang CC, Chen CY (2005) Degradation of azo dyes using low iron concentration of Fenton and Fentonlike system. Chemosphere 58:1409-1414

7. Pope MT (1983) Heteropoly and isopoly oxometalates. Springer, New York

8. Kuznetsova NI, Kirillova NV, Kuznetsova LI, Smirnova MY, Likholobov VA (2007) Hydrogen peroxide and oxygen oxidation of aromatic compounds in catalytic systems containing heteropoly compounds. J Hazard Mater 46:569-576

9. Bechiri O, Abbessi M, Belghiche R, Ouahab L (2014) WellsDawson polyoxometelates $\left[\mathrm{HP}_{2} \mathrm{~W}_{18-\mathrm{n}} \mathrm{Mo}_{\mathrm{n}} \mathrm{O}_{62}\right] \mathrm{Fe}_{2.5}, \quad \mathrm{xH}_{2} \mathrm{O}$; $\mathrm{n}=0$, 6: synthesis, spectroscopic characterization and catalytic application for dyes oxidation. C R Chim 17:135-140

10. Ciabrini JP, Contant R, Fruchart M (1983) Heteropolyblues: relationship between metal-oxygen-metal bridges and reduction behaviour of octadeca (molybdotungsto) diphosphate anions. Polyhedron 2:1229-1233

11. Djaneye-boundjou G, Amouzou E, Kodom T, Tchakala I, Anodi K, Bawa LM (2012) Photocatalytic degradation of orange II using mesoporous $\mathrm{TiO}_{2}(\mathrm{P} 25)$ and fenton reactive $\left(\mathrm{Fe} / \mathrm{H}_{2} \mathrm{O}_{2}\right)$. IJESMER 1:91-96

12. Bechiri O, Abbessi M, Ouahab L (2012) The oxidation study of methyl orange dye by hydrogen peroxide using Dawson-type heteropolyanions as catalysts. Res Chem Intermed 39:2945-2954

13. Bechiri O, Abbessi M, Samar ME (2013) Decolorization of organic dye (NBB) using $\mathrm{Fe}(\mathrm{III}) \mathrm{P}_{2} \mathrm{~W}_{12} \mathrm{Mo}_{5} / \mathrm{H}_{2} \mathrm{O}_{2}$ system. Desalin Water Treat 51:31-33

14. Gould DM, Spiro M, Griffith WP (2005) Mechanism of bleaching by peroxides: part 7 . The $\mathrm{pH}$ dependence of the oxometalate catalysed bleaching of methyl orange. J Mol Cat A Chem 242:176-181

15. Fan HJ, Huang ST, Chung WH, Jan JL, Lin WY, Chen CC (2009) Degradation pathways of crystal violet by Fenton and Fenton-like systems: condition optimization and intermediate separation and identification. J Hazard Mater 71:1032-1044

16. Modirshahla N, Behnajady MA, Ghanbary F (2007) Decolorization and mineralization of C.I. Acid Yellow 23 by Fenton and photo-Fenton processes. Dyes Pigments 73:305-310

17. Mylon SE, Quan S, Waite TD (2010) Process optimization in use of zero valent iron nanoparticles for oxidative transformations. Chemosphere 81:127-131 
18. Strukul G (1992) Catalytic oxidations with hydrogen peroxide as oxidant. Kluwer Academic, Dordrecht

19. Lucas MS, Peres JA (2006) Decolorization of the azo dye reactive black 5 by Fenton and photo-Fenton oxidation. Dyes Pigments 71:236-244

20. Sun JH, Shi SH, Lee YF, Sun SP (2009) Fenton oxidative decolorization of the azo dye Direct Blue 15 in aqueous solution. Chem Eng J 155:680-683

21. Tadolini B, Cabrini L (1988) On the mechanism of OH. scavenger action. Biochem J 253:931-933

22. Zheng J, Gao Z, He H, Yang S, Sun C (2016) Efficient degradation of Acid Orange 7 in aqueous solution by iron ore tailing Fenton-like process. Chemosphere 150:40-48

23. Lindsey M, Tarr M (2000) Quantitation of hydroxyl radical during Fenton oxidation following a single addition of iron and peroxide. Chemosphere 41:409-417

24. Overend R, Paraskevopoulos G (1978) Rates of OH radical reactions. 4. Reactions with methanol, ethanol, I-propanol, and 2-propanol at 296 K. J Phys Chem 82:12

25. Ramirez HJ, Costa CA, Madeira LM, Mata G, Vicente MA, Rojas-Cervantes ML, Lopez-Peinado AJ, Martin-Aranda RM
(2007) Fenton-like oxidation of Orange II solutions using heterogeneous catalysts based on saponite clay. Appl Catal B 71:44-56

26. Bauer C, Jacques P, Kalt A, Photochem J (2001) Photodegradation of an azo dye induced by visible light incident on the surface of TiO2. Photobiol A Chem 140:87-92

27. Ji F, Li C, Zhang J, Deng L (2011) Efficient decolorization of dye pollutants with $\mathrm{LiFe}\left(\mathrm{WO}_{4}\right)_{2}$ as a reusable heterogeneous Fentonlike catalyst. Desalination 269:284-290

28. Catrinescu C, Teodosiu C, Macoveanu M, Miehe-Brendle J, Dred RL (2003) Catalytic wet peroxide oxidation of phenol over Feexchanged pillared beidellite. Water Res 37:1154-1160

29. Zhang F, Feng C, Li W, Cui J (2014) Indirect electrochemical oxidation of dye wastewater containing acid orange 7 using Ti/ $\mathrm{RuO}_{2}$-Pt electrode. Int J Electrochem Sci 9:943-954

30. Wang J, Liu G, Lu H, Jin R, Zhou J (2012) Biodegradation of acid orange 7 and its auto-oxidative decolorization product in membrane-aerated biofilm reactor. Int Biodeterior Biodegrad $67: 73-77$ 